\title{
Ethnologies
}

\section{Making Music in the Polish Tatras: Tourists, Ethnographers, and Mountain Musicians. By Timothy J. Cooley. (Bloomington and Indianapolis: Indiana University Press, 2005. Pp. viii + 293, ISBN 0-253-34489-1)}

\section{Louise Wrazen}

Volume 30, numéro 2, 2008

Hommage à Peter Narváez

In Honour of Peter Narváez

URI : https://id.erudit.org/iderudit/019956ar

DOI : https://doi.org/10.7202/019956ar

Aller au sommaire du numéro

Éditeur(s)

Association Canadienne d'Ethnologie et de Folklore

ISSN

1481-5974 (imprimé)

1708-0401 (numérique)

Découvrir la revue

Citer ce compte rendu

Wrazen, L. (2008). Compte rendu de [Making Music in the Polish Tatras:

Tourists, Ethnographers, and Mountain Musicians. By Timothy J. Cooley.

(Bloomington and Indianapolis: Indiana University Press, 2005. Pp. viii + 293,

ISBN 0-253-34489-1)]. Ethnologies, 30(2), 277-282.

https://doi.org/10.7202/019956ar 
They are at least as important for lessons in performance as for that which is performed.

O verall, the "Back On Track" CD series is a valuable record of music making and oral traditions in N ewfoundland and Labrador, and serves as a model of accessibility and scholarship that I hope other archives might follow. A vailable for purchase from Landwash M usic (www.landwashdistribution.com) for about $\$ 20$ each, these CDs are well worth the price.

\section{H eather Sparling C ape B reton U niversity Sydney, N ova Scotia}

Making Music in the Polish Tatras: Tourists, Ethnographers, and Mounta in Musicians. By Timothy J. Cooley. (Bloomington and Indiana polis: Indiana University Press, 2005. Pp. viii + 293, ISBN 0-253-34489-1)

W hat impact do we have on those in the "field" of our research? Two decades of self-examination have explored the nature of fieldwork as an increasingly participatory, self-reflexive and dialogic process built on personal relationships and commensality. In a post-colonial, postmodern, global world, we are becoming increasingly aware of the range of implications that our work has inspired among the peoples and cultures we study. Timothy Cooley compellingly addresses such issues in his insightful examination of "outsider" involvement in the Podhale region of southern Poland. Located on the northern side of the Tatra M ountains that form part of the Carpathian M ountain crescent which extends from southern Poland into the Balkans, Podhale is home to the $\mathrm{G}$ órale (H ighlanders) and has a long history of association with outsiders despite its relatively isolated geographic position. In this book, the author explores constructions of ethnicity and music-culture as a direct corollary of the impact of tourists (long attracted to this mountainous region) and ethnographers (similarly attracted to a rich folk culture) in a study drawn from over ten years of research and fieldwork, and built on a dissertation and several published articles.

Locating his work in the tradition of Anderson (1991) and Hobsbawm and Ranger (1983), Cooley suggests that over a period of 
two centuries, tourists and ethnographers have joined with longtime residents of Podhale in imagining and inventing $G$ órale as a distinct ethnic group within Poland and the music-culture with which they are associated (4). Though isolation is the most frequently cited reason for the Gorale people's distinct cultural identity, Cooley builds upon this as an irony by suggesting that "outside interest also stimulated the very invention of Górale ethnicity and that it now provides, through the tourist industry, an important motivation for maintaining this ethnicity"(8). He goes on to detail the instrumental music, songs and dances that have come to identify the G órale of Podhale as both sound/ gesture and idea, and the way these have contributed to making and maintaining the $\mathrm{G}$ orale as a distinct ethnic group.

$M$ aking $M$ usic in the Polish Tatras comprises seven chapters in addition to an introduction and epilogue. These chapters fall into two main parts: the first three provide a historical orientation to the region, people, music-culture and scholarship; the second four revolve around the concept of the village in today's world and provide ongoing examples of change and adaptation. Each chapter situates the discussion within an expansive theoretical framework to contextualize specific ethnographic work within larger issues relevant to ethnomusicology, folklore, and anthropology in general. These include concerns with locality and place, tourism and ethnography, music and identity, nationalism and transnationalism - all within an ethnomusicological tradition engaged with the epistemological goal of understanding rather than explaining music-culture (Titon 1997).

Chapter 1 (Podhale) introduces the reader to this small region and people before focusing on the music-culture itself. $\mathrm{H}$ ere $\mathrm{C}$ ooley provides a comprehensive and systematic overview of the distinctive music associated with the Górale. Dividing it into vocal and instrumental genres, music for dancing, and dance genres, he provides transcriptions and recordings based on his own field research as well as published collections. This presents a fine introduction to a little-known repertoire about which there is a dearth of information in English (see also W razen 1988). (A brief observation here serves to illustrate some of the idiosyncrasies of ethnoaesthetics and local terminology in presenting repertoire: I have been told that the bass pattern defining Figure 1.8 would identify this as a wierchowa rather than ozwodna.) To conclude this chapter, the author describes his first (1992) encounter with this music in the field as an effective introduction to the themes explored in subsequent chapters. 
In Chapter 2 (M aking History), C ooley begins his examination of the construction of $\mathrm{G}$ orale ethnicity, arguing that the creation of this ethnic category was the result of various new migrations in the nineteenth and twentieth centuries. He here implicates ethnographers, in particular, as being "capable of creating the very thing they present as discovery" (61). Following an overview of histories of settlement of the Tatras, C ooley presents a fascinating view of "T he $\mathrm{M}$ issing $\mathrm{N}$ arrative: The ' $\mathrm{N}$ ew M igration." Comprising mostly members of an elite class with a disposable income (in contrast with earlier migrants and settlers in Podhale who were generally poor), these new migrants of the mid nineteenth and early twentieth centuries created a new sense of difference, amplified by inequality, among the Górale. Cooley argues that "these new migrants, their historical narratives and discourses on ethnicity, created the Górale ethnic group as it is understood today, and that in the process they closed off the possibility of new migrants to Podhale becoming Górale themselves"(74). Providing surveys of four waves of settlement from the late nineteenth century to the present, Cooley elaborates on the impact of this new migration as it helped both to codify symbols of difference (81), and to make the cultural practices by which that ethnicity has subsequently been maintained (82).

Chapter 3 (Making Mountain M usic: A H istory of Ethnography in Podhale) explores the way in which the music of Podhale (muzyka Podhala) was constructed as part of this identity. By combining fieldwork interviews among Górale musicians with meticulous examination of early collections and writings on this music, Cooley here effectively demonstrates that musical ethnographers are implicated in the very "making of the modern mountain music called muzyka Podhala"(84). Comparing O skar Kolberg's landmark collection of 1857 and 1863 with subsequent transcriptions, Cooley shows how a broad repertoire was streamlined by "culture brokers" (104) such as the popular promoter of the region, Dr. Tytus Chalubinski (1820-1889), who associated with prominent $\mathrm{G}$ órale musicians Jan K rzeptowski-Sabala and Bartolomiej 0 brochta, and how it was then subsequently canonized by the music scholar Stanislaw M ierczynski (1894-1952) with his two books of Górale instrumental tunes (1930) and songs (1935), against which all subsequent publications have been judged.

A ware of the potentially contentious nature of this position, C ooley is careful to stress that his argument is not intended to "denigrate the 
legendary independence and creativity of Górale" (122). Indeed, the second half of this book demonstrates ways in which the residents of Podhale have continued to adapt "to the changing socioeconomic climate introduced by the new migration while simultaneously maintaining a sense of distinctiveness" (122). Chapters 4 (Village on Stage), 5 (Global Village), 6 (Village for Hire) and 7 (Back to the Village) provide contemporary ethnographically based interpretations concerned with the concept of the village - a powerful trope in G órale culture and life.

Chapter 4 explores the now dominant world of song/dance troupes and festivals within a theoretical orientation indebted to Erving Goffman's "back region" and "front region" performance (1956), and here considered as a modern ritual of regional identity. Drawing heavily on the work of Barbara Kirshenblatt-Gimblett and Regina Bendix, the author presents a compelling examination of the Zakopane International Festival of Mountain Folklore in terms of a dynamic balance between the local and global, traditional and innovative, spurious and authentic, tourist and ethnographic, to explicate ways in which $\mathrm{G}$ órale now ensure themselves a place in today's world. Chapter 5 explores the effects of globalization on muzyka Podhala through a detailed musical analysis of selected recordings made in the 1990s by the famous Gorale family band, Trebunia-Tutki, with N orman G rant and his reggae band. C hapter 6 returns to the local scene, and focuses on one traditionally inspired restaurant in the heart of the town of Zakopane that features performances of $\mathrm{G}$ órale music and dance for tourists. A s a liminal space in which G órale "chose to exploit their identity in order to earn a living" (213), the restaurant setting offers Cooley an opportunity to reflect on his own shifting experiences as tourist, ethnographer, guest, friend, musician, dancer, local and outsider.

The final chapter considers the most traditional of settings - the wedding and the funeral - which Cooley regards as "moments of collective self-reflection" and "therefore significant locations for considering the relationships between musical-practice and the selfconceptions of individuals and communities" (240). Where he considers weddings in relation to Boym's theory of nostalgia (Boym 2001), he regards funerals as the most inward of "backstage" events in the community. Both reveal a cross section of the core and peripheral repertoires of Podhale, as defined in earlier chapters. Cooley's Epilogue (Village Exhumed) provides an elegant analysis of a recent song text 
("Zakopane U nearthed," by K. Trebunia-Tutka) which conveniently details insider/outsider binaries as a final reminder to the possibility of culture constructed, in this way providing an adroit conclusion to a carefully organized and well argued exploration of this people and musicculture.

The text is supplemented with numerous fine photographs and illustrations (many of historical interest), helpful transcriptions, a glossary of terms, and a CD containing forty-seven examples, including a notable 1914 wax cylinder recording of the legendary fiddler 0 brochta. A ny reservations I have are limited to details of translation (for example, some of the song texts; and on page 112 "W alczaka" probably refers to a tune belonging to Walczak, a surname referenced in dialect on page 246 as "Walcoki"), or typographical errors (notably page 238 "Ko[cielisko"), and in no way detract from the strength of this book.

In M aking M usic in the Polish Tatra, Timothy Cooley has succeeded in addressing a glaring lacuna in English-language publications in ethnomusicology on Eastern Europe. In addition, he has written an engaging work which should be of interest not only to ethnomusicologists, but also to folklorists and anthropologists. Clearly written, methodically presented, and meticulously documented, Cooley moves adroitly from one current theoretical issue to another, making notable contributions to research on ethnicity and identity formation, tourism and ethnography, historiography and formulations of regionalism that should provide essential reading for those interested in these areas.

Louise Wrazen

York U niversity

Toronto, 0 ntario

\section{References}

A nderson, Benedict. 1991 [1983]. Imagined communities: Reflections of the $\mathrm{O}$ rigin and Spread of $\mathrm{N}$ ationalisms. Rev. ed. London: Verso.

Boym, Svetlana. 2001. The Future of N ostalgia. N ew York: Basic Books. Goffman, Erving. 1956. The Presentation of Self in Everyday Life.

Edinburgh: University of Edinburgh Social Sciences Research Centre.

Hobsbawm, Eric, and Terence Rangers, eds. 1983. The Invention of Tradition. C ambridge: C ambridge U niversity Press. 
Titon, Jeff Todd. 1985. "Knowing Fieldwork." In G regory F. Barz and Timothy J. Cooley eds., Shadows in the Field: $\mathrm{N}$ ew Perspectives for Fieldwork in Ethnomusicology: 87-100. N ew York: Oxford U niversity Press.

W razen, Louise. 1988. "The Góralski of the Polish Highlanders: Old World Musical Traditions from a New World Perspective." PhD dissertation, U niversity of Toronto.

Tracking Doctor Lonecloud: Showman to Legend Keeper. By Ruth Holmes Whitehead. (Fredericton, NB: Goose Lane Editions \& Nova Scotia Museum, 2002. Pp. 183, ISBN 0864923562)

This delightful book includes the ethnography, folklore and cultural history of the nineteenth and early twentieth century $\mathrm{Mi}$ 'kmaq, as narrated by Jerry Lonecloud (a.k.a. Germain Bartlett A lexis) and told to Clara Dennis and Harry Piers. Ruth W hitehead has patiently and painstakingly sifted through Lonecloud's memoirs, stories and legends to present us with an insider's view of what it was like to grow up as a M i'kmaq in a white man's world. We learn how Lonecloud was taught the secrets of the medicine by his grandparents; how he received his name (from the white man who hired him to be part of his W ild West Medicine show because he wanted to sell Indian authenticity); and how he learned to adapt in the white man's world through appropriation (for example, in his legends and stories about medicine he often used the white man's terms, such as "tom-tom" or "squaw"). A s he said of himself, Jerry Lonecloud was a showman.

Throughout the book, we are enchanted by Lonecloud's reflections, insights, and humour. For example, in his discussion of missionaries, he explains how one priest in Nova Scotia would not leave the village until all of the people agreed to be christened and how this created change among them. Likewise, he talks about the M i'kmaq language, indicating that there were no curse words in their language until the white man came. of his responsibilities as a medicine man, he says that the chief medicine man was the keeper of the medicine and the storyteller. He could also marry people and often would be the village disciplinarian. Reading between the lines, we realize that the medicine 